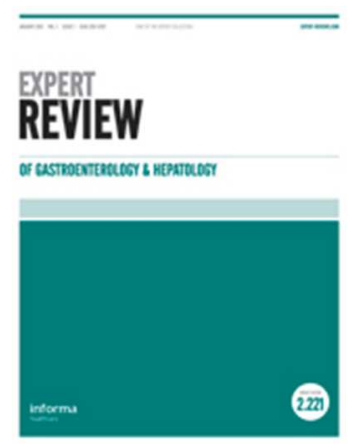

\title{
Current and Future Treatment Options in Non-Alcoholic Steatohepatitis (NASH)
}

\begin{tabular}{|r|l|}
\hline Journal: & Expert Review of Gastroenterology \& Hepatology \\
\hline Manuscript ID & ERH-2016-0167 \\
\hline Manuscript Type: & Reviews \\
\hline Keywords: & fibrosis, fatty liver, obeticholic acid, elafibranor, cirrhosis, bariatric surgery \\
\hline \multicolumn{2}{|c}{} \\
\hline
\end{tabular}

SCHOLARONE ${ }^{m}$

Manuscripts 
Current and Future Treatment Options in Non-Alcoholic Steatohepatitis (NASH)

1

2

3

4

5

6

7

8

9

10

11

12

13

14

15

16

17

18

19

20

21

22

23

24

25

26

27

28

29

30

31

32

33

34

35

36

37

38

39

40

41

42

43

44

45

46

47

48

49

50

51

52

53

54

55

56

57

58

59

60 


\begin{abstract}
Introduction: Non-alcoholic steatohepatitis (NASH) is a chronic liver disease that can progress to cirrhosis and hepatocellular carcinoma. Diagnosis of NASH requires liver biopsy and is defined as presence of hepatic steatosis and inflammation with or without fibrosis. Although NASH is the most common cause of liver disease in the west world and among the top three indications for liver transplantation, there are no universally accepted pharmacological therapies and advances have been slow.
\end{abstract}

Areas covered: Current evidence about lifestyle interventions, bariatric surgery and pharmacotherapy is reviewed. Dietary recommendations and lifestyle interventions have shown promising results but are difficult to maintain. At the moment, there is no universally approved medical treatment for NASH. Pioglitazone and vitamin E are recommended by guidelines in selected patients. An increasing number of phase II and III trials in non-cirrhotic NASH are currently recruiting and their preliminary results discussed.

Expert commentary: As NASH is classified as a medical condition of an unmet therapeutic need, it has gained an accelerated access pathway for drug approval based on surrogate endpoints. It is therefore expected that within the next five years, there will be at least one approved agent for the pharmacological treatment of pre-cirrhotic NASH.

Keywords: fibrosis, obeticholic acid, elafibranor, fatty liver, cirrhosis, bariatric surgery 


\subsection{Introduction}

Non-alcoholic fatty liver disease (NAFLD) is defined as the presence of hepatic steatosis in patients who do not consume excessive alcohol and who do not have other secondary causes of steatosis such as steatogenic medication $[1,2,3]$. It is considered the hepatic manifestation of the metabolic syndrome and is associated with type II diabetes, obesity and dyslipidaemia $[4,5,6]$. The prevalence of obesity and metabolic syndrome have increased exponentially over the recent years hence contributing to the rising prevalence of NAFLD [7]. NAFLD is projected to become the main indication for liver transplantation in the next 10 years $[2,3,8]$. Based on the histological features, NAFLD is differentiated in simple steatosis (NAFL) and nonalcoholic steatohepatitis (NASH) [2, 3], which is characterized by lobular inflammation, ballooning and higher risk of progression to cirrhosis [9]. Although there is rigorous scientific interest in approaching novel therapeutic pathways to treat $\mathrm{NASH}$, the gold standard remains lifestyle modification with a combination of weight loss and exercise $[10,11]$. During the last decades, a variety of different agents, which target specific pathophysiologic mechanisms, have been studied in controlled trials in the treatment of NASH. A better understanding of NAFLD pathogenesis will not only help clarify how the disease progresses but may also result in the discovery of new treatment strategies. Potential therapeutic targets and approaches include the use of insulin sensitizers, antioxidants/anti-inflammatory and anti-fibrotic agents. This review focuses on therapeutic approaches that have already been tested in patients with NASH, with a brief mention on promising future agents that are already at least in phase II trials. 


\subsection{Management principles}

NAFL is considered a benign condition and is not associated with increased liver-related morbidity hence no liver-specific treatment is required. The presence of coexisting conditions like diabetes mellitus, dyslipidaemia and obesity should be investigated and managed $[2,3]$. Conversely, patients with NASH might potentially progress to cirrhosis and treatment is necessary. Patients with NASH have increased risk of death from liver-related and cardiovascular causes [12].

\subsection{Diet and lifestyle modification / exercise}

NAFLD and NASH are strongly associated with the metabolic syndrome and the majority of patients are overweight or obese, with co-morbidities like diabetes mellitus or insulin resistance and hyperlipidemia. Hence the cornerstone of treatment is a combination of weight reduction and exercise through a combination of diet, physical activity and general lifestyle changes [13]. Behavioural change through diet and exercise may not suffice alone as other parameters are still under investigation, such as smoking, which is associated with increased insulin resistance and possibly with advanced liver fibrosis $[14,15]$.

From as early as 1970, studies indicated that weight loss is associated with improvement in liver histology as evidenced by follow up biopsies [16] and liver enzyme levels [17]. Small studies verified that weight reduction is correlated with lower levels of aminotransferases and showed that liver biochemistry was aggravated when patients regained weight [18]. The prevalence of metabolic syndrome in obese patients was also reduced when weight loss was achieved by diet and medical treatment [19]. Patients who accomplish a reduction of more than 5\% of their body weight have improved insulin sensitivity and steatosis. Furthermore, when patients 
lose more than $9 \%$ of body weight, ballooning, inflammation and nonalcoholic fatty liver disease score (NAS) are also improved [20].

A randomized controlled trial (RCT) with 31 patients tested the efficacy of intense dietary and lifestyle interventions with exercise compared with general education for 48 weeks. The lifestyle interventions arm achieved an average of $9.3 \%$ reduction of body weight versus $0.2 \%$ in the other group, which was also associated with a beneficial effect in liver histology since liver steatosis was improved. Overall a weight loss of more than $7 \%$ of body weight was linked to significant improvement in steatosis, lobular inflammation, ballooning and NAS, but not fibrosis. Whether liver fibrosis may not be affected as much from weight loss or whether a longer treatment period is needed, is unclear [11]. However a recent retrospective study of 45 patients showed regression of fibrosis when patients lost more than $10 \%$ of body weight regardless of the method used (bariatric therapy, diet, medical therapy for weight loss). In addition when patients regained weight, fibrosis worsened [21].

The largest clinical study thus far, assessed 293 individuals with biopsy proven NASH for one year. Patients received dietary advice, motivation to exercise and were instructed to $\log$ their daily caloric consumption and activities. Assessment of follow up biopsies recorded a $25 \%$ resolution of NASH and a $47 \%$ of NAS improvement. Improvement in portal inflammation and fibrosis was greater in patients with weight loss more than $10 \%$ of body weight. In total $19 \%$ of patients achieved regression of fibrosis after a year. It is noteworthy that from those patients who reached $10 \%$ of weight loss, $45 \%$ showed regression of fibrosis thus underlining the importance of weight reduction as well as the dose-response relationship between weight loss and hepatic histology improvement. On the other hand the majority of patients with deteriorating liver histology had minimal or no weight loss. In total, less 
than $50 \%$ of patients lost more than $7 \%$ of body weight and $25 \%$ achieved resolution of NASH questioning the efficacy of these interventions in real life where usually success rates are lower [22].

Published studies highlight the association between diet and exercise with improvement in the biochemical levels and histological findings of NAFLD patients [23]. Further supporting the role of dietary intervention, small studies displayed histological improvement though without statistical significance [24]. The focus of current research is to characterize unhealthy dietary habits for NAFLD patients. In this setting, a prospective study showed that NAFLD patients tend to consume more soft drinks and meat and less omega-3 fatty acids [25]. Similarly fructose consumption is increased in NAFLD patients and is associated with increased fibrosis [26]. Interestingly, diets with either restriction of fat or carbohydrate result in weight reduction [27] while the Mediterranean diet seems to improve liver steatosis and insulin sensitivity even without weight loss, albeit in a small group of patients [28].

Exercise, along with diet, is a key part of behavioral changes with both beneficial effects in cardiovascular risk factors and leading to body weight reduction [29]. Despite the fact that physical activity plays an important role in NAFLD management, the majority of patients do not exercise and fitness is inversely associated with the prevalence of NAFLD [30]. Indeed even when weight loss is not accomplished through exercise there are beneficial results from physical activity. A placebo controlled RCT of 19 sedentary obese patients assessed hepatic function by magnetic resonance imaging and blood testing after 4 weeks of aerobic training or placebo (stretching), documenting a reduction in hepatic triglyceride concentration [31]. In a similar study, resistance exercise decreased fat concentration in the liver, as 
measured by magnetic resonance, and ameliorated insulin resistance, glucose control and lipid oxidation, despite the fact that once again weight loss was not achieved [32].

Data from a recent meta-analysis suggests that exercise has a beneficial role in reducing intrahepatic lipids but not in the improvement of liver biochemistry even when weight reduction is minimal or none. The vast heterogeneity and small number of studies included in the analyses indicates that more research regarding exercise interventions is required in order to accurately assess its role in NAFLD treatment [33]. Furthermore the same researchers concluded that changes in the intensity or amount of aerobic exercise do not have a significant effect on liver fat reduction and fail to improve weight loss [34]. Despite this finding, a significant difference between all exercise groups and placebo was documented in regards to intrahepatic lipid and visceral adipose tissue, as measured by magnetic resonance [34].

\subsection{Orlistat}

Weight reduction through diet and lifestyle modification is advocated as the first line of intervention in NASH but the majority of real life patients are unable to comply with dietary modifications. Orlistat, an oral inhibitor of gastric and pancreatic lipases, was introduced in obese patients with NASH in order to assist with weight loss. Initially a case series of 3 patients showed marked improvement in histological and biochemical markers after 6 or 12 months of orlistat treatment [35]. In a RCT of 52 patients, orlistat in conjunction with a weight loss program reduced ALT levels and steatosis by ultrasound after 6 months. Interestingly, there was no significant difference in weight reduction between orlistat and placebo group [36]. Another RCT with fifty overweight patients demonstrated that the reduction of aminotransferases and body weight were similar when comparing treatment with vitamin E plus diet or 
vitamin E plus diet and orlistat. In addition, no improvement in liver histology was documented after 9 months of treatment regarding hepatic steatosis, ballooning, inflammation or fibrosis [20].

\subsection{Bariatric surgery}

Bariatric surgery is indicated in severely or morbidly obese patients and a variety of procedures have been performed. These procedures include bilio-intestinal bypass, gastric band, laparoscopic adjustable gastric banding, Roux-en-Y gastric bypass and sleeve gastrectomy. Jejuno-ileal bypass was abandoned because of liver complications that developed after surgery ranging from increased fatty infiltration to cirrhosis and liver failure [37]. The majority of patients undergoing bariatric procedures also have NAFLD. A recent Cochrane review found insufficient data from RCTs and quasi-randomised clinical studies in order to consider bariatric surgery as a therapeutic resource in patients with NASH [38]. Although recommendations have not yet established bariatric procedures as an eligible treatment for NAFLD and $\mathrm{NASH}$, weight loss is known to increase insulin sensitivity and also act beneficially to visceral fat loss [39].

In a small study, laparoscopic adjustable gastric band placement was associated with sustained weigh loss and improved liver biochemistry and insulin sensitivity. Follow up biopsies indicated that steatosis, inflammation, ballooning and fibrosis also reduced, although a lot of patients had to undergo revision surgery [40]. A prospective study from France evaluated the presence of fibrosis and non-alcoholic steatohepatitis in 381 obese patients after bariatric surgery. They concluded that the majority of patients had decreased steatosis and ballooning after one and five years, albeit inflammation remained unchanged compared with baseline measurements. The 
most significant improvement was observed the first year after the procedure and was sustained. Interestingly, there was a statistically significant increase in fibrosis but with low fibrosis score of F1 or less at 5 years [41]. Conversely a recent study presented evidence of improvement of fibrosis along with the histological features of NAFLD in liver biopsies after bariatric surgery [42]. Intriguingly, steatosis and inflammation resolved in $75 \%$ and fibrosis of any grade improved in half of the 160 patients, although the second liver biopsy was done in different time intervals and was not always accompanied with biochemical liver markers. The team from Lille published a new study that included 109 obese patients, over the last twenty years, who had a follow up liver biopsy one year after bariatric surgery. Body mass index, insulin resistance index and other markers were significant improved and NASH disappeared from $85 \%$ of the patients [43]. Bariatric surgery induced histological improvement of NASH and fibrosis amelioration. The persistence of NASH was correlated with less weight loss and refractory insulin resistance.

In conclusion, foregut bariatric surgery is not yet an established treatment of NASH and more RCTs are awaited. However, it is frequently practiced in overweight non-cirrhotic NAFLD patients with encouraging results.

\subsubsection{Insulin sensitizing agents}

There is a well-documented association between non-alcoholic steatohepatitis and the metabolic syndrome. This association has led to a rigorous investigation of the majority of type 2 diabetes regimens for the treatment of NAFLD and NASH.

\subsubsection{Metformin}


One of the first anti-diabetic agents assessed in NASH was metformin. A comparison between metformin, vitamin $\mathrm{E}$ and diet alone exhibited the benefit of metformin in an open label, randomized trial with 110 patients, by improving aminotransferases levels and decreasing liver fat and necroinflammation in a limited number of 17 patients [44]. Besides liver function tests improvement, metformin facilitated weight loss and had a beneficial role in necroinflammation and fibrosis in a small number of patients as shown in the follow up biopsy. However more recent trials have not confirmed these results, as metformin did not to have a significant effect neither on liver histology nor on liver biochemical results [45]. In a double blind, placebo-controlled RCT with 173 patients, metformin did not significantly improve liver biochemistry or histology in children and adolescents with NAFLD and NASH [46]. Furthermore, metformin provided no additional benefit when combined with another anti-diabetic agent such as rosiglitazone [47]. Although metformin does not improve NASH, there is evidence that it might reduce the incidence of hepatocellular carcinoma. In a recent nationwide case control study from Taiwan with 97,430 HCC patients and 194,960 matched controls, the use of metformin was associated with a decreased risk of HCC in a dose dependent manner, as HCC risk was reduced by $7 \%$ for each incremental year of metformin use [48].

\subsubsection{Thiazolidinediones}

Pioglitazone and rosiglitazone are agonists of the nuclear peroxisome proliferator activated receptor-gamma (PPAR $\gamma)$, thus acting by improving insulin sensitivity. The effect of rosiglitazone and pioglitazone on liver biochemistry and histology (steatosis, ballooning, inflammation and fibrosis) has been vigorously investigated in NASH both in diabetic and non-diabetic patients. 
In 2008, the FLIRT RCT tested the effect of rosiglitazone in 63 patients with biopsy-proven NASH for one year. Steatosis and transaminase levels improved after treatment, although fibrosis and other histology scores remained unchanged. There was a documented increase in weight in the rosiglitazone group due to peripheral oedema [49]. The study showed a rapid reduction in liver biochemistry in the first months of treatment and a gradual return to baseline levels after the end of the treatment period. An extension of this trial was designed aiming to assess further histological improvement with longer treatment. Unfortunately the goal of fibrosis regression was not achieved and no additional benefit was documented after 2 years of treatment [50]. Researchers attempted to combine rosiglitazone with other agents like metformin and losartan however the results were not as promising [47]. Moreover, rosiglitazone has been associated with an increased risk of myocardial infarction and heart failure and as a result is no more accessible in Europe [51, 52].

In a pilot study of 18 non-diabetic patients with NASH treated with pioglitazone for 48 weeks, liver biochemistry and histology significantly improved [53]. This improvement may be modulated by an adiponectin-mediated effect on insulin sensitivity and hepatic fatty acid metabolism rather than by changes in proinflammatory cytokines [54]. In a RCT of pioglitazone and dietary restriction versus diet restriction alone in 55 patients with NASH, pioglitazone significantly improved all histological measures apart from fibrosis [55]. Interestingly discontinuation of pioglitazone treatment reverses the beneficial effects on aminotransferase levels and inflammation markers [54]. In a UK RCT of 74 patients, pioglitazone treatment for 12 months resulted in significant weight gain and improvements in metabolic and histological parameter, including liver fibrosis [56]. 
The PIVENS trial was the largest RCT to assess the use of pioglitazone in biopsy proven NASH compared with vitamin E or placebo therapy. 247 non-diabetic patients were randomized in three groups and received vitamin E, pioglitazone or placebo for 96 weeks with additional lifestyle and dietary recommendations. Pioglitazone was associated with significant reductions in hepatic steatosis, lobular inflammation and resolution of steatohepatitis as compared with placebo although no improvement in fibrosis was seen. The study concluded that there was no benefit of pioglitazone over placebo since the drug failed to meet the pre-specified level of significance for the improvement in histologic findings [57].

There are adverse effects of pioglitazone that need to be acknowledged. Congestive heart failure increases with pioglitazone, nevertheless without an associated increase in cardiovascular mortality [58, 59]. Furthermore, pioglitazone presents the same side effect profile with the other thiazolidinediones regarding weight gain, bone loss and pedal edema [60].

Pioglitazone is included in the AASLD and EASL management recommendations for patients with biopsy proven NASH although the optimal duration of treatment is yet to be determined $[2,3]$. However the long-term efficacy is debatable and the experience with rosiglitazone suggests no additional benefit with longer therapy schemes [50]. Moreover both biochemical and histological improvement return to baseline after treatment discontinuation while weight gain is not easily reversible [54].

\subsubsection{Liraglutide}

Liraglutide is a glucagon-like peptide-1 (GLP-1) analogue with longer duration and was introduced for the treatment of diabetes mellitus in obese patients in 
2009 [61]. Liraglutide improves glycaemic control and promotes weight loss [62], with only minor adverse events initially documented. Liraglutide and other GLP-1 analogues have two advantages. Firstly, they have been used for a number of years already in other diseases and thus the safety profile in known. Secondly, they improve to a large extent the metabolic syndrome parameters that are implicated in NASH, hence making them attractive therapeutic options. Liraglutide was recently investigated in 52 patients in a phase II double blind RCT in patients with NASH, with the primary outcome being resolution of NASH and no deterioration of fibrosis [63]. The results were promising and showed that $39 \%(9 / 23)$ of patients in the liraglutide group had resolution of the histological features of NASH compared to $9 \%$ $(2 / 22)$ of patients in the placebo arm. In addition, patients in the liraglutide arm had significantly reduced weight and BMI at the end of treatment compared with those that received placebo.

\subsubsection{Sitagliptin}

Sitagliptin, a dipeptidyl peptidase 4 (DDP-4 inhibitor) is another anti hyperglycemic agent studied in animal models with hopeful results [64]. An open label observational pilot study with $15 \mathrm{NASH}$ patients with diabetes assessed the effect of sitagliptin for one year. Paired liver biopsies revealed a significant decrease in ballooning and histological activity scores [65]. However, when further trials evaluated sitagliptin on patients with $\mathrm{NASH}$, one study was terminated early (NCT01260246) and another was withdrawn prior to enrollment (NCT02263677). In a recent RCT of sitagliptin for 24 weeks in 50 NAFLD patients, there was no significant reduction in liver fat as measured by MRI in comparison with the placebo group [66]. 


\subsection{Statins and ezetimibe}

One of the main therapies for dyslipidaemia are statins, hence the efficacy of this agents has also been assessed in the treatment of NASH but without robust results. The use of statins is indicated in patients with NASH and dyslipidaemia in order to reduce cardiovascular risk, however there is no strong evidence yet to prove that they can improve or delay liver disease progression. A prospective randomised open label study from Greece with 1600 patients, demonstrated a significant improvement of liver enzymes in patients receiving atorvastatin albeit no liver histology was assessed with biopsy after treatment [67]. Patients underwent liver biopsy after a year of statin therapy in small studies from USA and Japan, though with conflicting results. Simvastatin appeared to have no effect on the histopathological signs of NASH [68], however pravastatin leads to improvement of the biochemical markers and even histology in some patients [69]. Nevertheless, progression of fibrosis was evident is some patients. Recently a prospective open label uncontrolled study with 20 NASH patients reported resolution of NASH after 12 months of monotherapy with rosuvastatin $(10 \mathrm{mg} / \mathrm{d})$. All patients underwent liver biopsy before and after treatment and although body weight and waist circumference remained unchanged, 19 patients had histological resolution of NASH [70]. Furthermore statin use was associated with a reduction in incident of hepatocellular carcinoma among patients with diabetes and $\mathrm{HCV}$ in large cohorts of patients $[71,72]$.

A recent double blind, placebo-controlled RCT with 50 biopsy proven NASH patients examined the efficacy of ezetimibe $(10 \mathrm{mg} / \mathrm{d})$ for 24 weeks mainly by assessing liver fat change as measured by magnetic resonance imaging and was negative [73]. 


\subsection{Polyunsaturated fatty acids (PUFAs) - Omega-3 fatty acids}

In both animal and human intervention trials it was suggested that polyunsaturated fatty acids (PUFA) had an impact on both lipid metabolism and insulin sensitivity through multiple pathways. Thus it has been hypothesized that PUFA supplementation, which cannot be synthesized by mammals, can have beneficial effect on NAFLD [74]. Administration of eicosapentaenoic acid and docosahexaenoic acid for 48 weeks showed no positive effect over placebo on both histological markers and insulin resistance or lipid control [75]. In a phase 2 RCT in 243 patients with biopsy proven NASH, two dosages of ethyl-eicosapentaenoic acid were tested and no histological improvement was demonstrated after one year of treatment, whilst the effect on serum triglycerides appeared moderate [76]. A possible explanation for those negative results is the lack of an optimal dosage of polyunsaturated fatty acids hence higher dosages should be used and standardised according to their lipid lowering effect.

\subsection{Ursodeoxycholic acid (UDCA)}

UDCA, a bile acid, was thought to be a promising treatment for NASH based on small pilot studies with the potential to improve liver biochemistry and histology. In the first large RCT including 166 patients, no significant difference between the UDCA (13-15 mg/Kgr/day) and placebo was identified in biochemistry or histology [77]. The result was partially attributed to low dosage and a higher dosage of UDCA (23-28 mg/Kgr/day) was tried in a further RCT that included 185 patients for 18 months [78]. Nonetheless, the result remained the same and no liver histology improvement was documented regardless of the histological score used. Hence the 
EASL and AASLD guidelines do not recommend the use of UDCA in NAFLD or NASH patients $[2,3]$.

\subsection{Vitamin E}

The hypothesis that an antioxidant agent such as vitamin E (a-tocopherol) can ameliorate liver histology has been frequently tested in NASH patients. Vitamin E improved histological findings in a small double-blind RCT of 49 patients and a prospective open label study of 23 patients after 6 and 12 months of treatment respectively $[79,80]$. In those studies the number of patients was small and the dosage and formulation of vitamin $\mathrm{E}$ was variable. A combination with pioglitazone was initially tested in a small randomized prospective trial with 20 NASH patients with positive results [81]. Lately the PIVENS and TONIC studies assessed the efficacy of vitamin $\mathrm{E}$ in large numbers of patients with biopsy confirmed NASH in adult and paediatric populations respectively. The PIVENS study compared pioglitazone with vitamin $\mathrm{E}$ and placebo for 96 weeks and demonstrated the superiority of vitamin $\mathrm{E}$ over placebo in the improvement of liver histology [57]. When compared to placebo, vitamin E treatment demonstrated a higher percentage of NAS score improvement (43\% vs. 19\%) and liver biochemistry improvement [57]. In the children and adolescents cohort, although vitamin E was not superior to placebo in ALT reduction, it resulted in significantly higher resolution of NASH [46]. Both PIVENS and TONIC used 800IU/day of vitamin E for duration of 96 weeks but neither presented sufficient evidence of regression of fibrosis. When vitamin E was used as the control treatment in a study that combined metformin and bicyclol, the histological features of steatosis, inflammation and ballooning were decreased in both groups [82]. On account of those results, EASL and AASLD guidelines consider vitamin $\mathrm{E}$ as a potential short term treatment for non-diabetic NASH patients $[2,3]$ despite a potential increase in all- 
cause mortality, haemorrhagic stroke and prostate cancer that has been documented $[83,84,85]$.

\subsection{Obeticholic acid (6a-ethyl-chenodeoxycholic acid)}

A very promising agent that has emerged from animal and human studies is obeticholic acid, a bile acid derivative that acts as an agonist of the farnesoid $\mathrm{X}$ receptor (FXR). Bile acids might interfere in the metabolic pathways of glucose and lipids through the FXR [86]. In a small RCT of 64 diabetic patients with NASH, obeticholic acid administered for 6 weeks increased insulin sensitivity and reduced liver biochemical markers compared to placebo in the expense of a rise in LDL levels [87]. A large, multicentre RCT of obeticholic acid versus placebo for 72 weeks was subsequently performed in 283 patients with biopsy proven NASH [88]. The obeticholic acid group showed improved liver histology compared with placebo, including fibrosis, ballooning, steatosis and inflammation. Furthermore obeticholic acid was associated with weight loss. The most common adverse event were the presence of pruritus, elevated LDL and reduced HDL cholesterol levels in the obeticholic acid group that reversed after treatment [88]. Albeit the presence of pruritus and the rise of total and LDL cholesterol, obeticholic acid appears to be a promising agent for the treatment of $\mathrm{NASH}$, once long term safety is assured and is currently tested in a phase III trial (NCT02548351).

\subsection{Elafibranor}

Elafibranor (formerly known as GFT505) is a dual peroxisome proliferatoractivated receptor alpha/delta agonist ( $\mathrm{PPAR} \alpha / \delta$ agonist), which provided some hopeful results in patients with metabolic syndrome and obesity [89, 90]. Human liver PPAR $\alpha$ gene expression negatively correlates with NASH severity, while histological 
improvement is associated with an increase in expression of PPAR $\alpha$ and its target genes [91]. In animal models of NAFLD/NASH, elafibranor improved liver histology by both PPAR-a dependent and -independent mechanisms [92]. Subsequently elafibranor was introduced in a double blind placebo controlled RCT with 276 noncirrhotic NASH patients in two doses of $80 \mathrm{mg}$ and $120 \mathrm{mg}$ daily for 52 weeks in order to define histological response. The primary outcome of reversal of NASH without worsening of fibrosis was not achieved in the elafibranor arms compared with placebo. Nevertheless, when a post hoc analysis assessed the response using a modified definition of NASH resolution, the 120mg arm exhibited a significant improvement. Furthermore liver biochemistry, glucose and lipids profiles were reduced as well, without weight gain [93]. An ongoing phase III trial will further evaluate the efficacy and long term safety of elafibranor versus placebo in NASH patients (NCT02704403).

\subsection{The future}

Future research for effective pharmacotherapy treatment in NAFLD and NASH is challenging. A lot of agents are being investigated and some emerging data from rodent trials are promising. As NASH pathogenesis and progression are illuminated, more potential therapeutic targets emerge [94]. Novel drugs aim at multiple targets and pathways, such as inflammation and oxidative stress, the gut liver axis, the metabolic factor and progression of fibrosis [95].

Aramchol, a fatty acid-bile conjugate is a potential therapeutic agent which seems to reduce liver fat as assessed by magnetic resonance spectroscopy [96]. An ongoing trial is recruiting patients to evaluate the efficacy and safety of two aramchol doses versus placebo in NASH patients (NCT02279524). Volixibat (SHP-626), is an 
apical sodium dependent bile acid transporter inhibitor (ASBTi) and is being evaluated in an ongoing phase 2 RTC for 48 weeks. The primary outcome measures the effect of volixibat on liver histology (NCT02787304).

Saroglitazar is a dual PPAR agonist that has demonstrated significant improvement in glycemic and lipid control in diabetic patients and appears to ameliorate aminotransferases in 31 NAFLD patients after 24 weeks [97]. A series of trials from India are evaluating potential benefits from this agent [98]. A RCT evaluated a pradigastat, which is a diacylglycerol acyltransferase-1 inhibitor, in 52 NAFLD patients for 24 weeks with two different doses. Pradigastat improved liver fat after 12 and 24 weeks when administered at the high dose (10/20 mg/day) [99].

An inhibitor of phosphodiesterase-4 (ASP9831) with promising results from a phase 1 trial was evaluated in 93 patients with NASH compared with placebo but no significant change was observed in liver biochemistry after 12 weeks of administration at either of the two investigated doses [100]. In murine models of NASH, a pan-caspase inhibitor, emricasan (IDN-6556) reduced hepatocyte apoptosis and consequently attenuated liver injury and fibrosis [101]. Emricasan significantly reduced transaminases after 28 days in 38 patients with NAFLD [102]. A larger RCT is currently recruiting participants (NCT02686762).

Cenicriviroc, a dual CCR2/CCR5 antagonist is evaluated in a phase $2 \mathrm{~b}$ randomized, double blind, placebo controlled study with 289 NASH patients for a period of 2 years [103].

GS-6624 (simtuzumab) is a monoclonal antibody against lysyl oxidase-like 2 (LOXL2) and GS-4497 is a molecule that inhibits apoptosis signal-regulating kinase 1 (ASK1) which acts as a mediator of oxidative stress. Both these agents are being 
tested in at least three ongoing clinical trials to assess the efficacy of simtuzumab alone or in combination with GS-4997 in patients with NASH with and without cirrhosis. (NCT02466516, NCT01672866, NCT01672879). Finally anti-CD3 antibodies that reduce insulin resistance in animals were included in small trial designs for NASH patients and leaded to positive results demanding further research in the immediate future [104].

\subsection{Conclusions}

There is a documented global increase of NAFLD and NASH related to the epidemic of the metabolic syndrome and obesity leading to increasing morbidity, mortality and associated health costs. The research for better understanding the pathogenesis of NASH and determining new biomarkers of prognosis, disease progression and regression is of cardinal importance. This needs to take into account influence of genetics and the molecular mechanisms that are associated with the progression from NAFLD to NASH and which are not completely understood. Of the available therapeutic options, weigh loss of at least $10 \%$ results in resolution of NASH and fibrosis in the majority of patients within one year. No pharmacological treatment to date has produced such results. Pioglitazone and vitamin E are the only treatments that are recommended in the EASL and AASLD guidelines in selected cases, however both are associated with side effects and their long-term safety and efficacy are questionable. There is an increasing interest from the pharmaceutical industry in conducting studies in NASH, which will hopefully result in effective treatments in the years to come.

\subsection{Expert commentary}


NAFLD is a slowly progressing disease and expected liver-related outcome take more than 25 years to occur. It is therefore unrealistic to expect the conduction of trials of such duration. The Federal Drug Agency (FDA) in the US has agreed to the use of a co-primary endpoint for trials in pre-cirrhotic NASH that consists of resolution of steatohepatitis without worsening of fibrosis or improvement in the fibrosis score without worsening of the steatohepatitis. This will grant approval through the accelerated access pathway, with the sponsor obligation to conduct a post-market trial to demonstrate that the improvement in these surrogate end-points translates into a clinical meaningful benefit to patients [105]. The presence or severity of NASH has not been associated with clinical outcomes in long-term cohort studies [106], whereas only the presence of advanced fibrosis was associated with liver-related events [107]. Moreover, there is significant intra- and inter-observer variability in the assessment of the NAS score, which has so far jeopardized the outcome of well-conducted RCTs $[57,93]$. Therefore, the resolution of NASH endpoint (or any decrease of the NAS score) is of questionable utility. We propose the exploration of quantitative fibrosis assessment using the collagen proportionate area as a surrogate endpoint, that would allow for the detection of finer changes in fibrosis and could potentially shorten the duration of clinical trials $[108,109,110]$. CPA assessment would probably require a modified method to capture and measure the finer pericellular fibrosis which is present in NASH.

Moreover, the identification of clinically relevant biomarkers of disease regression that could potentially alleviate the need for serial biopsies and would increase study recruitment is an unmet need. A current innovative medicines initiative call, which represents a collaboration between the European Commission and the European pharmaceutical industry, will hopefully address this issue. 
Since NASH has multiple potential pathways of development, combination treatment will also be explored at some point in the future. Ultimately, if there are no large scale interventions from a public health policy perspective to actively implement changes in lifestyle, the toll of morbidity and mortality will continue to rise irrespective of any small scale success in pharmaceutical therapy.

\subsection{Five-year view}

At the moment, there are promising agents in large scale phase III trials (obeticholic acid, elafibranor) and others in phase II trials (cenicriviroc, simtuzumbab, volixibat) that target different pathways of NASH development and progression. As NASH is classified as a medical condition of an unmet therapeutic need, it has gained an accelerated access pathway for drug approval based on surrogate endpoints. It is therefore expected that within the next five years, there will be at least one approved agent for the pharmacological treatment of pre-cirrhotic NASH. It is also expected that biomarker research will have identified candidate markers that will allow better characterization of patients and reduce the need for a liver biopsy.

\subsection{Key issues}

* NAFLD has become the most common cause for chronic liver disease in the developed world.

* Dietary and lifestyle interventions provide beneficial results but are difficult to maintain in the long term.

* Although there is no universally approved medical treatment, both the EASL and AASLD guidelines suggest pioglitazone and vitamin E use in selected cases.

* As NASH is classified as a medical condition of an unmet therapeutic need, it has gained an accelerated access pathway for drug approval based on surrogate endpoints. 
* New agents as obeticholic acid and elafibranor have shown promising results in phase II and are currently in phase III trials.

* Novel drugs aim at multiple targets and pathways, such as inflammation and oxidative stress, the gut liver axis, the metabolic factor and progression of fibrosis.

* The exploration of surrogate outcomes with clinical relevance, such as quantitative fibrosis assessment using the collagen proportionate area, and biomarkers of disease progression and regression is important. 


\section{REFERENCES}

Reference annotations

* Of interest

** Of considerable interest

1. Williams CD, Stengel J, Asike MI, Torres DM, Shaw J, Contreras M, Landt

CL, Harrison SA. Prevalence of nonalcoholic fatty liver disease and nonalcoholic steatohepatitis among a largely middle-aged population utilizing ultrasound and liver biopsy: a prospective study. Gastroenterology. 2011;140:124-31.

2. Chalasani N, Younossi Z, Lavine JE, Diehl AM, Brunt EM, Cusi K, Charlton M, Sanyal AJ, American Association for the Study of Liver D, American College of G, American Gastroenterological A. The diagnosis and management of non-alcoholic fatty liver disease: Practice guideline by the American Association for the Study of Liver Diseases, American College of Gastroenterology, and the American Gastroenterological Association. The American journal of gastroenterology. 2012;107:811-26.

3. European Association for the Study of the Liver . Electronic address eee, European Association for the Study of D, European Association for the Study of O. EASL-EASD-EASO Clinical Practice Guidelines for the management of nonalcoholic fatty liver disease. Journal of hepatology. 2016;64:1388-402.

** The European Association for the Study of the Liver (EASL) latest guidelines for an updated management of non-alcoholic fatty liver disease.

4. Adiels M, Taskinen MR, Boren J. Fatty liver, insulin resistance, and dyslipidemia. Current diabetes reports. 2008;8:60-4.

5. Koehler EM, Plompen EP, Schouten JN, Hansen BE, Darwish Murad S, Taimr P, Leebeek FW, Hofman A, Stricker BH, Castera L, Janssen HL. Presence of diabetes 
mellitus and steatosis is associated with liver stiffness in a general population: The Rotterdam study. Hepatology. 2016;63:138-47.

6. Buzzetti E, Pinzani M, Tsochatzis EA. The multiple-hit pathogenesis of nonalcoholic fatty liver disease (NAFLD). Metabolism: clinical and experimental. 2016;65:1038-48.

7. Finkelstein EA, Khavjou OA, Thompson H, Trogdon JG, Pan L, Sherry B, Dietz W. Obesity and severe obesity forecasts through 2030. American journal of preventive medicine. $2012 ; 42: 563-70$.

8. Charlton MR, Burns JM, Pedersen RA, Watt KD, Heimbach JK, Dierkhising RA. Frequency and outcomes of liver transplantation for nonalcoholic steatohepatitis in the United States. Gastroenterology. 2011;141:1249-53.

9. Bugianesi E, Leone N, Vanni E, Marchesini G, Brunello F, Carucci P, Musso A, De Paolis P, Capussotti L, Salizzoni M, Rizzetto M. Expanding the natural history of nonalcoholic steatohepatitis: from cryptogenic cirrhosis to hepatocellular carcinoma. Gastroenterology. 2002;123:134-40.

10. Kantartzis K, Thamer C, Peter A, Machann J, Schick F, Schraml C, Konigsrainer A, Konigsrainer I, Krober S, Niess A, Fritsche A, Haring HU, Stefan N. High cardiorespiratory fitness is an independent predictor of the reduction in liver fat during a lifestyle intervention in non-alcoholic fatty liver disease. Gut. 2009;58:12818.

11. Promrat K, Kleiner DE, Niemeier HM, Jackvony E, Kearns M, Wands JR, Fava JL, Wing RR. Randomized controlled trial testing the effects of weight loss on nonalcoholic steatohepatitis. Hepatology. 2010;51:121-9. 
12. Ekstedt M, Franzen LE, Mathiesen UL, Thorelius L, Holmqvist M, Bodemar G, Kechagias S. Long-term follow-up of patients with NAFLD and elevated liver enzymes. Hepatology. 2006;44:865-73.

13. Harrison SA, Day CP. Benefits of lifestyle modification in NAFLD. Gut. $2007 ; 56: 1760-9$

14. Zein CO, Unalp A, Colvin R, Liu YC, McCullough AJ, Nonalcoholic Steatohepatitis Clinical Research N. Smoking and severity of hepatic fibrosis in nonalcoholic fatty liver disease. Journal of hepatology. 2011;54:753-9.

15. Tsochatzis EA, Papatheodoridis GV. Smoking is associated with histological severity in nonalcoholic steatohepatitis. Hepatology. 2010;52:1522-3.

16. Drenick EJ, Simmons F, Murphy JF. Effect on hepatic morphology of treatment of obesity by fasting, reducing diets and small-bowel bypass. The New England journal of medicine. 1970;282:829-34.

17. Palmer M, Schaffner F. Effect of weight reduction on hepatic abnormalities in overweight patients. Gastroenterology. 1990;99:1408-13.

18. Hickman IJ, Jonsson JR, Prins JB, Ash S, Purdie DM, Clouston AD, Powell EE. Modest weight loss and physical activity in overweight patients with chronic liver disease results in sustained improvements in alanine aminotransferase, fasting insulin, and quality of life. Gut. 2004;53:413-9.

19. Phelan S, Wadden TA, Berkowitz RI, Sarwer DB, Womble LG, Cato RK, Rothman R. Impact of weight loss on the metabolic syndrome. International journal of obesity. 2007;31:1442-8.

20. Harrison SA, Fecht W, Brunt EM, Neuschwander-Tetri BA. Orlistat for overweight subjects with nonalcoholic steatohepatitis: A randomized, prospective trial. Hepatology. 2009;49:80-6. 
21. Glass LM, Dickson RC, Anderson JC, Suriawinata AA, Putra J, Berk BS, Toor A. Total body weight loss of $>/=10 \%$ is associated with improved hepatic fibrosis in patients with nonalcoholic steatohepatitis. Digestive diseases and sciences. 2015;60:1024-30.

22. Vilar-Gomez E, Martinez-Perez Y, Calzadilla-Bertot L, Torres-Gonzalez A, Gra-Oramas B, Gonzalez-Fabian L, Friedman SL, Diago M, Romero-Gomez M. Weight Loss Through Lifestyle Modification Significantly Reduces Features of Nonalcoholic Steatohepatitis. Gastroenterology. 2015;149:367-78 e5; quiz e14-5.

* A study that demostrates the importance of weight loss for the improvement of hepatic histology.

23. Ueno T, Sugawara H, Sujaku K, Hashimoto O, Tsuji R, Tamaki S, Torimura T, Inuzuka S, Sata M, Tanikawa K. Therapeutic effects of restricted diet and exercise in obese patients with fatty liver. Journal of hepatology. 1997;27:103-7.

24. Huang MA, Greenson JK, Chao C, Anderson L, Peterman D, Jacobson J, Emick D, Lok AS, Conjeevaram HS. One-year intense nutritional counseling results in histological improvement in patients with non-alcoholic steatohepatitis: a pilot study. The American journal of gastroenterology. 2005;100:1072-81.

25. Zelber-Sagi S, Nitzan-Kaluski D, Goldsmith R, Webb M, Blendis L, Halpern Z, Oren R. Long term nutritional intake and the risk for non-alcoholic fatty liver disease (NAFLD): a population based study. Journal of hepatology. 2007;47:711-7.

26. Abdelmalek MF, Suzuki A, Guy C, Unalp-Arida A, Colvin R, Johnson RJ, Diehl AM, Nonalcoholic Steatohepatitis Clinical Research N. Increased fructose consumption is associated with fibrosis severity in patients with nonalcoholic fatty liver disease. Hepatology. 2010;51:1961-71. 
27. Haufe S, Engeli S, Kast P, Bohnke J, Utz W, Haas V, Hermsdorf M, Mahler

A, Wiesner S, Birkenfeld AL, Sell H, Otto C, Mehling H, Luft FC, Eckel J, SchulzMenger J, Boschmann M, Jordan J. Randomized comparison of reduced fat and reduced carbohydrate hypocaloric diets on intrahepatic fat in overweight and obese human subjects. Hepatology. 2011;53:1504-14.

28. Ryan MC, Itsiopoulos C, Thodis T, Ward G, Trost N, Hofferberth S, O'Dea K, Desmond PV, Johnson NA, Wilson AM. The Mediterranean diet improves hepatic steatosis and insulin sensitivity in individuals with non-alcoholic fatty liver disease. Journal of hepatology. 2013;59:138-43.

29. Goodpaster BH, Delany JP, Otto AD, Kuller L, Vockley J, South-Paul JE, Thomas SB, Brown J, McTigue K, Hames KC, Lang W, Jakicic JM. Effects of diet and physical activity interventions on weight loss and cardiometabolic risk factors in severely obese adults: a randomized trial. Jama. 2010;304:1795-802.

30. Church TS, Kuk JL, Ross R, Priest EL, Biltoft E, Blair SN. Association of cardiorespiratory fitness, body mass index, and waist circumference to nonalcoholic fatty liver disease. Gastroenterology. 2006;130:2023-30.

31. Johnson NA, Sachinwalla T, Walton DW, Smith K, Armstrong A, Thompson MW, George J. Aerobic exercise training reduces hepatic and visceral lipids in obese individuals without weight loss. Hepatology. 2009;50:1105-12.

32. Hallsworth K, Fattakhova G, Hollingsworth KG, Thoma C, Moore S, Taylor R, Day CP, Trenell MI. Resistance exercise reduces liver fat and its mediators in nonalcoholic fatty liver disease independent of weight loss. Gut. 2011;60:1278-83.

33. Keating SE, Hackett DA, George J, Johnson NA. Exercise and non-alcoholic fatty liver disease: a systematic review and meta-analysis. Journal of hepatology. 2012;57:157-66. 
34. Keating SE, Hackett DA, Parker HM, O'Connor HT, Gerofi JA, Sainsbury A, Baker MK, Chuter VH, Caterson ID, George J, Johnson NA. Effect of aerobic exercise training dose on liver fat and visceral adiposity. Journal of hepatology. $2015 ; 63: 174-82$.

35. Harrison SA, Ramrakhiani S, Brunt EM, Anbari MA, Cortese C, Bacon BR. Orlistat in the treatment of NASH: a case series. The American journal of gastroenterology. 2003;98:926-30.

36. Zelber-Sagi S, Kessler A, Brazowsky E, Webb M, Lurie Y, Santo M, Leshno M, Blendis L, Halpern Z, Oren R. A double-blind randomized placebo-controlled trial of orlistat for the treatment of nonalcoholic fatty liver disease. Clinical gastroenterology and hepatology : the official clinical practice journal of the American Gastroenterological Association. 2006;4:639-44.

37. Haines NW, Baker AL, Boyer JL, Glagov S, Schneir H, Jaspan J, Ferguson DJ. Prognostic indicators of hepatic injury following jejunoileal bypass performed for refractory obesity: a prospective study. Hepatology. 1981;1:161-7.

38. Chavez-Tapia NC, Tellez-Avila FI, Barrientos-Gutierrez T, Mendez-Sanchez N, Lizardi-Cervera J, Uribe M. Bariatric surgery for non-alcoholic steatohepatitis in obese patients. The Cochrane database of systematic reviews. 2010:CD007340.

39. Berzigotti A, Saran U, Dufour JF. Physical activity and liver diseases. Hepatology. 2016;63:1026-40.

40. Dixon JB, Bhathal PS, Hughes NR, O'Brien PE. Nonalcoholic fatty liver disease: Improvement in liver histological analysis with weight loss. Hepatology. 2004;39:1647-54.

41. Mathurin P, Hollebecque A, Arnalsteen L, Buob D, Leteurtre E, Caiazzo R, Pigeyre M, Verkindt H, Dharancy S, Louvet A, Romon M, Pattou F. Prospective 
study of the long-term effects of bariatric surgery on liver injury in patients without advanced disease. Gastroenterology. 2009;137:532-40.

42. Taitano AA, Markow M, Finan JE, Wheeler DE, Gonzalvo JP, Murr MM. Bariatric surgery improves histological features of nonalcoholic fatty liver disease and liver fibrosis. Journal of gastrointestinal surgery : official journal of the Society for Surgery of the Alimentary Tract. 2015;19:429-36; discussion 36-7.

43. Lassailly G, Caiazzo R, Buob D, Pigeyre M, Verkindt H, Labreuche J, Raverdy V, Leteurtre E, Dharancy S, Louvet A, Romon M, Duhamel A, Pattou F, Mathurin P. Bariatric Surgery Reduces Features of Nonalcoholic Steatohepatitis in Morbidly Obese Patients. Gastroenterology. 2015;149:379-88; quiz e15-6.

44. Bugianesi E, Gentilcore E, Manini R, Natale S, Vanni E, Villanova N, David E, Rizzetto M, Marchesini G. A randomized controlled trial of metformin versus vitamin $\mathrm{E}$ or prescriptive diet in nonalcoholic fatty liver disease. The American journal of gastroenterology. 2005;100:1082-90.

45. Shields WW, Thompson KE, Grice GA, Harrison SA, Coyle WJ. The Effect of Metformin and Standard Therapy versus Standard Therapy alone in Nondiabetic Patients with Insulin Resistance and Nonalcoholic Steatohepatitis (NASH): A Pilot Trial. Therapeutic advances in gastroenterology. 2009;2:157-63.

46. Lavine JE, Schwimmer JB, Van Natta ML, Molleston JP, Murray KF, Rosenthal P, Abrams SH, Scheimann AO, Sanyal AJ, Chalasani N, Tonascia J, Unalp A, Clark JM, Brunt EM, Kleiner DE, Hoofnagle JH, Robuck PR, Nonalcoholic Steatohepatitis Clinical Research N. Effect of vitamin E or metformin for treatment of nonalcoholic fatty liver disease in children and adolescents: the TONIC randomized controlled trial. Jama. 2011;305:1659-68. 
* Metformin did not significantly improved liver histology in children and adolescents with NAFLD and NASH.

47. Torres DM, Jones FJ, Shaw JC, Williams CD, Ward JA, Harrison SA. Rosiglitazone versus rosiglitazone and metformin versus rosiglitazone and losartan in the treatment of nonalcoholic steatohepatitis in humans: a 12-month randomized, prospective, open- label trial. Hepatology. 2011;54:1631-9.

48. Chen HP, Shieh JJ, Chang CC, Chen TT, Lin JT, Wu MS, Lin JH, Wu CY. Metformin decreases hepatocellular carcinoma risk in a dose-dependent manner: population-based and in vitro studies. Gut. 2013;62:606-15.

49. Ratziu V, Giral P, Jacqueminet S, Charlotte F, Hartemann-Heurtier A, Serfaty L, Podevin P, Lacorte JM, Bernhardt C, Bruckert E, Grimaldi A, Poynard T, Group LS. Rosiglitazone for nonalcoholic steatohepatitis: one-year results of the randomized placebo-controlled Fatty Liver Improvement with Rosiglitazone Therapy (FLIRT) Trial. Gastroenterology. 2008;135:100-10.

50. Ratziu V, Charlotte F, Bernhardt C, Giral P, Halbron M, Lenaour G, Hartmann-Heurtier A, Bruckert E, Poynard T, Group LS. Long-term efficacy of rosiglitazone in nonalcoholic steatohepatitis: results of the fatty liver improvement by rosiglitazone therapy (FLIRT 2) extension trial. Hepatology. 2010;51:445-53.

51. Nissen SE, Wolski K. Effect of rosiglitazone on the risk of myocardial infarction and death from cardiovascular causes. The New England journal of medicine. 2007;356:2457-71.

52. Home PD, Pocock SJ, Beck-Nielsen H, Curtis PS, Gomis R, Hanefeld M, Jones NP, Komajda M, McMurray JJ, Team RS. Rosiglitazone evaluated for cardiovascular outcomes in oral agent combination therapy for type 2 diabetes (RECORD): a multicentre, randomised, open-label trial. Lancet. 2009;373:2125-35. 
53. Promrat K, Lutchman G, Uwaifo GI, Freedman RJ, Soza A, Heller T, Doo E, Ghany M, Premkumar A, Park Y, Liang TJ, Yanovski JA, Kleiner DE, Hoofnagle JH. A pilot study of pioglitazone treatment for nonalcoholic steatohepatitis. Hepatology. 2004;39:188-96.

54. Lutchman G, Modi A, Kleiner DE, Promrat K, Heller T, Ghany M, Borg B, Loomba R, Liang TJ, Premkumar A, Hoofnagle JH. The effects of discontinuing pioglitazone in patients with nonalcoholic steatohepatitis. Hepatology. 2007;46:424-9. 55. Belfort R, Harrison SA, Brown K, Darland C, Finch J, Hardies J, Balas B, Gastaldelli A, Tio F, Pulcini J, Berria R, Ma JZ, Dwivedi S, Havranek R, Fincke C, DeFronzo R, Bannayan GA, Schenker S, Cusi K. A placebo-controlled trial of pioglitazone in subjects with nonalcoholic steatohepatitis. The New England journal of medicine. 2006;355:2297-307.

56. Aithal GP, Thomas JA, Kaye PV, Lawson A, Ryder SD, Spendlove I, Austin AS, Freeman JG, Morgan L, Webber J. Randomized, placebo-controlled trial of pioglitazone in nondiabetic subjects with nonalcoholic steatohepatitis. Gastroenterology. 2008;135:1176-84.

57. Sanyal AJ, Chalasani N, Kowdley KV, McCullough A, Diehl AM, Bass NM, Neuschwander-Tetri BA, Lavine JE, Tonascia J, Unalp A, Van Natta M, Clark J, Brunt EM, Kleiner DE, Hoofnagle JH, Robuck PR, Nash CRN. Pioglitazone, vitamin E, or placebo for nonalcoholic steatohepatitis. The New England journal of medicine. 2010;362:1675-85.

* An important study investigating the role of pioglitazone and vitamin E in NASH. 58. Lincoff AM, Wolski K, Nicholls SJ, Nissen SE. Pioglitazone and risk of cardiovascular events in patients with type 2 diabetes mellitus: a meta-analysis of randomized trials. Jama. 2007;298:1180-8. 
59. Lago RM, Singh PP, Nesto RW. Congestive heart failure and cardiovascular death in patients with prediabetes and type 2 diabetes given thiazolidinediones: a meta-analysis of randomised clinical trials. Lancet. 2007;370:1129-36.

60. Shah P, Mudaliar S. Pioglitazone: side effect and safety profile. Expert opinion on drug safety. 2010;9:347-54.

61. Buse JB, Rosenstock J, Sesti G, Schmidt WE, Montanya E, Brett JH, Zychma M, Blonde L, Group L-S. Liraglutide once a day versus exenatide twice a day for type 2 diabetes: a 26-week randomised, parallel-group, multinational, open-label trial (LEAD-6). Lancet. 2009;374:39-47.

62. Astrup A, Rossner S, Van Gaal L, Rissanen A, Niskanen L, Al Hakim M, Madsen J, Rasmussen MF, Lean ME, Group NNS. Effects of liraglutide in the treatment of obesity: a randomised, double-blind, placebo-controlled study. Lancet. 2009;374:1606-16.

63. Armstrong MJ, Gaunt P, Aithal GP, Barton D, Hull D, Parker R, Hazlehurst JM, Guo K, team Lt, Abouda G, Aldersley MA, Stocken D, Gough SC, Tomlinson JW, Brown RM, Hubscher SG, Newsome PN. Liraglutide safety and efficacy in patients with non-alcoholic steatohepatitis (LEAN): a multicentre, double-blind, randomised, placebo-controlled phase 2 study. Lancet. 2016;387:679-90.

* Liraglutide can ameliorate liver histology in NASH patients compared with placebo and reduce body weight at the same time.

64. Jung YA, Choi YK, Jung GS, Seo HY, Kim HS, Jang BK, Kim JG, Lee IK, Kim MK, Park KG. Sitagliptin attenuates methionine/choline-deficient diet-induced steatohepatitis. Diabetes research and clinical practice. 2014;105:47-57. 
65. Yilmaz Y, Yonal O, Deyneli O, Celikel CA, Kalayci C, Duman DG. Effects of sitagliptin in diabetic patients with nonalcoholic steatohepatitis. Acta gastroenterologica Belgica. 2012;75:240-4.

66. Cui J, Philo L, Nguyen P, Hofflich H, Hernandez C, Bettencourt R, Richards L, Salotti J, Bhatt A, Hooker J, Haufe W, Hooker C, Brenner DA, Sirlin CB, Loomba R. Sitagliptin vs. placebo for non-alcoholic fatty liver disease: A randomized controlled trial. Journal of hepatology. 2016;65:369-76.

67. Athyros VG, Tziomalos K, Gossios TD, Griva T, Anagnostis P, Kargiotis K, Pagourelias ED, Theocharidou E, Karagiannis A, Mikhailidis DP, Group GSC. Safety and efficacy of long-term statin treatment for cardiovascular events in patients with coronary heart disease and abnormal liver tests in the Greek Atorvastatin and Coronary Heart Disease Evaluation (GREACE) Study: a post-hoc analysis. Lancet. 2010;376:1916-22.

68. Nelson A, Torres DM, Morgan AE, Fincke C, Harrison SA. A pilot study using simvastatin in the treatment of nonalcoholic steatohepatitis: A randomized placebo-controlled trial. Journal of clinical gastroenterology. 2009;43:990-4.

69. Hyogo H, Ikegami T, Tokushige K, Hashimoto E, Inui K, Matsuzaki Y, Tokumo H, Hino F, Tazuma S. Efficacy of pitavastatin for the treatment of nonalcoholic steatohepatitis with dyslipidemia: An open-label, pilot study. Hepatology research : the official journal of the Japan Society of Hepatology. 2011;41:1057-65.

70. Kargiotis K, Athyros VG, Giouleme O, Katsiki N, Katsiki E, Anagnostis P, Boutari C, Doumas M, Karagiannis A, Mikhailidis DP. Resolution of non-alcoholic steatohepatitis by rosuvastatin monotherapy in patients with metabolic syndrome. World journal of gastroenterology. 2015;21:7860-8. 
71. Simon TG, Bonilla H, Yan P, Chung RT, Butt AA. Atorvastatin and fluvastatin are associated with dose-dependent reductions in cirrhosis and HCC, among patients with HCV Results from ERCHIVES. Hepatology. 2016.

72. El-Serag HB, Johnson ML, Hachem C, Morgana RO. Statins are associated with a reduced risk of hepatocellular carcinoma in a large cohort of patients with diabetes. Gastroenterology. 2009;136:1601-8.

73. Loomba R, Sirlin CB, Ang B, Bettencourt R, Jain R, Salotti J, Soaft L, Hooker J, Kono Y, Bhatt A, Hernandez L, Nguyen P, Noureddin M, Haufe W, Hooker C, Yin M, Ehman R, Lin GY, Valasek MA, Brenner DA, Richards L, San Diego Integrated NRC. Ezetimibe for the treatment of nonalcoholic steatohepatitis: assessment by novel magnetic resonance imaging and magnetic resonance elastography in a randomized trial (MOZART trial). Hepatology. 2015;61:1239-50.

74. Di Minno MN, Russolillo A, Lupoli R, Ambrosino P, Di Minno A, Tarantino G. Omega-3 fatty acids for the treatment of non-alcoholic fatty liver disease. World journal of gastroenterology. 2012;18:5839-47.

75. Dasarathy S, Dasarathy J, Khiyami A, Yerian L, Hawkins C, Sargent R, McCullough AJ. Double-blind randomized placebo-controlled clinical trial of omega 3 fatty acids for the treatment of diabetic patients with nonalcoholic steatohepatitis. Journal of clinical gastroenterology. 2015;49:137-44.

76. Sanyal AJ, Abdelmalek MF, Suzuki A, Cummings OW, Chojkier M, Group E-AS. No significant effects of ethyl-eicosapentanoic acid on histologic features of nonalcoholic steatohepatitis in a phase 2 trial. Gastroenterology. 2014;147:377-84 e1. 77. Lindor KD, Kowdley KV, Heathcote EJ, Harrison ME, Jorgensen R, Angulo P, Lymp JF, Burgart L, Colin P. Ursodeoxycholic acid for treatment of nonalcoholic steatohepatitis: results of a randomized trial. Hepatology. 2004;39:770-8. 
78. Leuschner UF, Lindenthal B, Herrmann G, Arnold JC, Rossle M, Cordes HJ, Zeuzem S, Hein J, Berg T, Group NS. High-dose ursodeoxycholic acid therapy for nonalcoholic steatohepatitis: a double-blind, randomized, placebo-controlled trial. Hepatology. 2010;52:472-9.

79. Harrison SA, Torgerson S, Hayashi P, Ward J, Schenker S. Vitamin E and vitamin $\mathrm{C}$ treatment improves fibrosis in patients with nonalcoholic steatohepatitis. The American journal of gastroenterology. 2003;98:2485-90.

80. Kawanaka M, Nishino K, Nakamura J, Suehiro M, Goto D, Urata N, Oka T, Kawamoto H, Nakamura H, Yodoi J, Hino K, Yamada G. Treatment of nonalcoholic steatohepatitis with vitamins E and C: a pilot study. Hepatic medicine : evidence and research. 2013;5:11-6.

81. Sanyal AJ, Mofrad PS, Contos MJ, Sargeant C, Luketic VA, Sterling RK, Stravitz RT, Shiffman ML, Clore J, Mills AS. A pilot study of vitamin E versus vitamin $\mathrm{E}$ and pioglitazone for the treatment of nonalcoholic steatohepatitis. Clinical gastroenterology and hepatology : the official clinical practice journal of the American Gastroenterological Association. 2004;2:1107-15.

82. Han Y, Shi JP, Ma AL, Xu Y, Ding XD, Fan JG. Randomized, vitamin Econtrolled trial of bicyclol plus metformin in non-alcoholic fatty liver disease patients with impaired fasting glucose. Clinical drug investigation. 2014;34:1-7.

83. Bjelakovic G, Nikolova D, Gluud LL, Simonetti RG, Gluud C. Mortality in randomized trials of antioxidant supplements for primary and secondary prevention: systematic review and meta-analysis. Jama. 2007;297:842-57.

84. Klein EA, Thompson IM, Jr., Tangen CM, Crowley JJ, Lucia MS, Goodman PJ, Minasian LM, Ford LG, Parnes HL, Gaziano JM, Karp DD, Lieber MM, Walther PJ, Klotz L, Parsons JK, Chin JL, Darke AK, Lippman SM, Goodman GE, Meyskens 
FL, Jr., Baker LH. Vitamin E and the risk of prostate cancer: the Selenium and Vitamin E Cancer Prevention Trial (SELECT). Jama. 2011;306:1549-56.

85. Schurks M, Glynn RJ, Rist PM, Tzourio C, Kurth T. Effects of vitamin E on stroke subtypes: meta-analysis of randomised controlled trials. Bmj. 2010;341:c5702.

86. Lefebvre P, Cariou B, Lien F, Kuipers F, Staels B. Role of bile acids and bile acid receptors in metabolic regulation. Physiological reviews. 2009;89:147-91.

87. Mudaliar S, Henry RR, Sanyal AJ, Morrow L, Marschall HU, Kipnes M, Adorini L, Sciacca CI, Clopton P, Castelloe E, Dillon P, Pruzanski M, Shapiro D. Efficacy and safety of the farnesoid $\mathrm{X}$ receptor agonist obeticholic acid in patients with type 2 diabetes and nonalcoholic fatty liver disease. Gastroenterology. 2013;145:574-82 e1.

88. Neuschwander-Tetri BA, Loomba R, Sanyal AJ, Lavine JE, Van Natta ML, Abdelmalek MF, Chalasani N, Dasarathy S, Diehl AM, Hameed B, Kowdley KV, McCullough A, Terrault N, Clark JM, Tonascia J, Brunt EM, Kleiner DE, Doo E, Network NCR. Farnesoid X nuclear receptor ligand obeticholic acid for non-cirrhotic, non-alcoholic steatohepatitis (FLINT): a multicentre, randomised, placebo-controlled trial. Lancet. 2015;385:956-65.

** The first large RCT assesing the benefitial role of obeticholic acid in NASH patients. Obeticholic acid group showed improved liver histology compared with placebo, including fibrosis, ballooning, steatosis and inflammation.

89. Cariou B, Zair Y, Staels B, Bruckert E. Effects of the new dual PPAR alpha/delta agonist GFT505 on lipid and glucose homeostasis in abdominally obese patients with combined dyslipidemia or impaired glucose metabolism. Diabetes care. 2011;34:2008-14. 
90. Cariou B, Hanf R, Lambert-Porcheron S, Zair Y, Sauvinet V, Noel B, Flet L, Vidal H, Staels B, Laville M. Dual peroxisome proliferator-activated receptor alpha/delta agonist GFT505 improves hepatic and peripheral insulin sensitivity in abdominally obese subjects. Diabetes care. 2013;36:2923-30.

91. Francque S, Verrijken A, Caron S, Prawitt J, Paumelle R, Derudas B, Lefebvre P, Taskinen MR, Van Hul W, Mertens I, Hubens G, Van Marck E, Michielsen P, Van Gaal L, Staels B. PPARalpha gene expression correlates with severity and histological treatment response in patients with non-alcoholic steatohepatitis. Journal of hepatology. 2015;63:164-73.

92. Staels B, Rubenstrunk A, Noel B, Rigou G, Delataille P, Millatt LJ, Baron M, Lucas A, Tailleux A, Hum DW, Ratziu V, Cariou B, Hanf R. Hepatoprotective effects of the dual peroxisome proliferator-activated receptor alpha/delta agonist, GFT505, in rodent models of nonalcoholic fatty liver disease/nonalcoholic steatohepatitis. Hepatology. 2013;58:1941-52.

93. Ratziu V, Harrison SA, Francque S, Bedossa P, Lehert P, Serfaty L, RomeroGomez M, Boursier J, Abdelmalek M, Caldwell S, Drenth J, Anstee QM, Hum D, Hanf R, Roudot A, Megnien S, Staels B, Sanyal A, Group G-IS. Elafibranor, an Agonist of the Peroxisome Proliferator-Activated Receptor-alpha and -delta, Induces Resolution of Nonalcoholic Steatohepatitis Without Fibrosis Worsening. Gastroenterology. 2016;150:1147-59 e5.

* The first RCT study with elafibranor in NASH patients failed to achieve the primary outcome of reversal of NASH.

94. Musso G, Cassader M, Gambino R. Non-alcoholic steatohepatitis: emerging molecular targets and therapeutic strategies. Nature reviews Drug discovery. 2016;15:249-74. 
** A recent review about new compounds and molecules for NASH treatment based on the different pathogenic pathways.

95. Rotman Y, Sanyal AJ. Current and upcoming pharmacotherapy for nonalcoholic fatty liver disease. Gut. 2016.

96. Safadi R, Konikoff FM, Mahamid M, Zelber-Sagi S, Halpern M, Gilat T, Oren R, Group F. The fatty acid-bile acid conjugate Aramchol reduces liver fat content in patients with nonalcoholic fatty liver disease. Clinical gastroenterology and hepatology : the official clinical practice journal of the American Gastroenterological Association. 2014;12:2085-91 e1.

97. Saboo B, Prajapati A, Joshi S, Bhandari S, Shah A, Jaiswal A, Hasnani D. To Assess the Effect of $4 \mathrm{mg}$ Saroglitazar on Patients of Diabetes Dyslipidemia with Nonalcoholic Fatty Liver Disease for 24 Weeks at Diabetes Care Centre (712-P2015). https://ada.scientificposters.com/epsAbstractADA.cfm?id=1: American Diabetes Association [online]; 2015.

98. Joshi S, Ghosh S, Shah P, Jaiswal A, Patel P. Saroglitazar in diabetic dyslipidemia: $\quad 1 \quad$ year data. (126-LB-2015). https://ada.scientificposters.com/epsAbstractADA.cfm?id=1: American Diabetes Association [online]; 2015.

99. Sanyal AJ, Cusi K, Patel S, Wright M, Liu C, Keefe D. Effect of pradigastat, a diacylglycerol acyltransferase 1 inhibitor, on liver fat content in nonalcoholic fatty liver disease. Hepatology 62 (Suppl. 1), 1253A (2015).2015.

100. Ratziu V, Bedossa P, Francque SM, Larrey D, Aithal GP, Serfaty L, Voiculescu M, Preotescu L, Nevens F, De Ledinghen V, Kirchner GI, Trunecka P, Ryder SD, Day CP, Takeda J, Traudtner K. Lack of efficacy of an inhibitor of PDE4 in phase 1 and 2 trials of patients with nonalcoholic steatohepatitis. Clinical 
gastroenterology and hepatology : the official clinical practice journal of the American Gastroenterological Association. 2014;12:1724-30 e5.

101. Barreyro FJ, Holod S, Finocchietto PV, Camino AM, Aquino JB, Avagnina A, Carreras MC, Poderoso JJ, Gores GJ. The pan-caspase inhibitor Emricasan (IDN6556) decreases liver injury and fibrosis in a murine model of non-alcoholic steatohepatitis. Liver international : official journal of the International Association for the Study of the Liver. 2015;35:953-66.

102. Shiffman M, Freilich B, Vuppalanchi R, Watt K, Burgess G, Morris M, Sheedy B, Schiff E. A placebo-controlled, multicenter, double-blind, randomised trial of emricasan in subjects with non-alcoholic fatty liver disease (NAFLD) and raised transaminases (LP37). J Hepatology 2015;62:S282-S.2015.

103. Friedman S, Sanyal A, Goodman Z, Lefebvre E, Gottwald M, Fischer L, Ratziu V. Efficacy and safety study of cenicriviroc for the treatment of non-alcoholic steatohepatitis in adult subjects with liver fibrosis: CENTAUR Phase $2 \mathrm{~b}$ study design. Contemporary clinical trials. 2016;47:356-65.

104. Lalazar G, Mizrahi M, Turgeman I, Adar T, Ben Ya'acov A, Shabat Y, Nimer A, Hemed N, Zolotarovya L, Lichtenstein Y, Lisovoder N, Samira S, Shalit I, Ellis R, Ilan Y. Oral Administration of OKT3 MAb to Patients with NASH, Promotes Regulatory T-cell Induction, and Alleviates Insulin Resistance: Results of a Phase IIa Blinded Placebo-Controlled Trial. Journal of clinical immunology. 2015;35:399-407.

105. Sanyal AJ, Miller V. Regulatory Science and Drug Approval for Alcoholic and Nonalcoholic Steatohepatitis. Gastroenterology. 2016;150:1723-7.

*Recent developments in the principals of drug approval for NASH through surrogate end points. 
106. Soderberg C, Stal P, Askling J, Glaumann H, Lindberg G, Marmur J, Hultcrantz R. Decreased survival of subjects with elevated liver function tests during a 28-year follow-up. Hepatology. 2010;51:595-602.

* Patients with NASH exhibit increased mortality compared with the general population in Sweden.

107. Ekstedt M, Hagstrom H, Nasr P, Fredrikson M, Stal P, Kechagias S, Hultcrantz R. Fibrosis stage is the strongest predictor for disease-specific mortality in NAFLD after up to 33 years of follow-up. Hepatology. 2015;61:1547-54.

108. Tsochatzis E, Bruno S, Isgro G, Hall A, Theocharidou E, Manousou P, Dhillon AP, Burroughs AK, Luong TV. Collagen proportionate area is superior to other histological methods for sub-classifying cirrhosis and determining prognosis. Journal of hepatology. 2014;60:948-54.

109. Manousou P, Dhillon AP, Isgro G, Calvaruso V, Luong TV, Tsochatzis E, Xirouchakis E, Kalambokis G, Cross TJ, Rolando N, O'Beirne J, Patch D, Thornburn D, Burroughs AK. Digital image analysis of liver collagen predicts clinical outcome of recurrent hepatitis $\mathrm{C}$ virus 1 year after liver transplantation. Liver transplantation : official publication of the American Association for the Study of Liver Diseases and the International Liver Transplantation Society. 2011;17:178-88.

110. Calvaruso V, Dhillon AP, Tsochatzis E, Manousou P, Grillo F, Germani G, Patch D, O'Beirne J, Burroughs AK. Liver collagen proportionate area predicts decompensation in patients with recurrent hepatitis $\mathrm{C}$ virus cirrhosis after liver transplantation. Journal of gastroenterology and hepatology. 2012;27:1227-32.

111. Wong VW, Wong GL, Chan AW, Chu WC, Choi PC, Chim AM, Yiu KK, Yu J, Chan FK, Chan HL. Treatment of non-alcoholic steatohepatitis with Phyllanthus 
urinaria: a randomized trial. Journal of gastroenterology and hepatology. 2013;28:5762.

112. Malaguarnera M, Gargante MP, Russo C, Antic T, Vacante M, Malaguarnera M, Avitabile T, Li Volti G, Galvano F. L-carnitine supplementation to diet: a new tool in treatment of nonalcoholic steatohepatitis--a randomized and controlled clinical trial. The American journal of gastroenterology. 2010;105:1338-45.

113. Vilar Gomez E, Rodriguez De Miranda A, Gra Oramas B, Arus Soler E, Llanio Navarro R, Calzadilla Bertot L, Yasells Garcia A, Del Rosario Abreu Vazquez M. Clinical trial: a nutritional supplement Viusid, in combination with diet and exercise, in patients with nonalcoholic fatty liver disease. Alimentary pharmacology \& therapeutics. 2009;30:999-1009. 
Table 1. Randomized controlled trials in patients with non-alcoholic steatohepatitis that included more than 50 patients and used liver histology as the primary outcome.

\begin{tabular}{|c|c|c|c|c|c|c|}
\hline $\mathrm{A} / \mathrm{a}$ & Author & $\begin{array}{l}\text { Number of } \\
\text { patients }\end{array}$ & Intervention & Duration & $\begin{array}{l}\text { Primary } \\
\text { Outcome }\end{array}$ & Result \\
\hline 1 & $\begin{array}{l}\text { Ratziu V, } \\
2016 \text { [93] }\end{array}$ & 276 patients & $\begin{array}{l}\text { Elafibranor } \\
2: 1 \\
\\
\end{array}$ & 52 weeks & $\begin{array}{l}\text { Resolution of } \\
\text { steatohepatitis } \\
\text { without } \\
\text { worsening of } \\
\text { fibrosis }\end{array}$ & Predefined end point not met \\
\hline 2 & $\begin{array}{l}\text { Armstrong } \\
\text { M.J, } 2016 \\
{[63]}\end{array}$ & 52 patients & $\begin{array}{l}\text { Liraglutide } \\
(1.8 \mathrm{mg}) 1: 1\end{array}$ & 48 weeks & $\begin{array}{l}\text { Resolution of } \\
\text { steatohepatitis } \\
\text { without } \\
\text { worsening of } \\
\text { fibrosis }\end{array}$ & Significant effect \\
\hline 3 & $\begin{array}{l}\text { Neuschwa } \\
\text { nder-Tetri } \\
\text { B, } 2015 \\
\text { (FLINT) } \\
{[88]}\end{array}$ & 283 patients & $\begin{array}{l}\text { Obeticholic } \\
\text { acid } \\
(25 \mathrm{mg} / \mathrm{d}) 1: 1\end{array}$ & 72 weeks & $\begin{array}{l}\text { Improvement } \\
\text { of NAS by at } \\
\text { least } 2 \text { points, } \\
\text { without } \\
\text { worsening of } \\
\text { fibrosis }\end{array}$ & Significant effect \\
\hline 4 & $\begin{array}{l}\text { Sanyal A, } \\
2014[76]\end{array}$ & 243 patients & $\begin{array}{l}\text { Ethyl- } \\
\text { Eicosapentan } \\
\text { oic Acid }\end{array}$ & 12 months & $\begin{array}{l}\text { Improvement } \\
\text { of NAS, } \\
\text { without }\end{array}$ & No significant effect \\
\hline
\end{tabular}




\begin{tabular}{|c|c|c|c|c|c|c|}
\hline & & & (EPA-E) $2: 1$ & & $\begin{array}{l}\text { worsening of } \\
\text { fibrosis }\end{array}$ & \\
\hline 5 & $\begin{array}{l}\text { Wong } \\
\text { VW, } 2013 \\
{[111]}\end{array}$ & 60 patients & $\begin{array}{l}\text { Phyllanthus } \\
\text { urinaria } \\
\text { (herb) } 2: 1\end{array}$ & 24 weeks & $\begin{array}{l}\text { Change in } \\
\text { NAFLD } \\
\text { activity score }\end{array}$ & No significant effect \\
\hline 6 & $\begin{array}{l}\text { Torres D, } \\
2011[47]\end{array}$ & 137 patients & $\begin{array}{l}\text { Rosiglitazone } \\
\text { vs } \\
\text { Rosiglitazone } \\
\& \text { metformin } \\
\text { vs } \\
\text { rosiglitazone } \\
\& \quad \text { losartan } \\
1: 1: 1\end{array}$ & 12 months & $\begin{array}{l}\text { Improvement } \\
\text { of steatosis, } \\
\text { inflammationa } \\
\text { nd fibrosis }\end{array}$ & No significant effect \\
\hline 7 & $\begin{array}{l}\text { Lavine J, } \\
2011 \\
\text { (TONIC) } \\
\text { in children } \\
{[46]}\end{array}$ & 173 patients & $\begin{array}{l}\text { Vitamin E vs. } \\
\text { metformin } \\
\text { vs. Placebo } \\
1: 1: 1\end{array}$ & 96 weeks & $\begin{array}{l}\text { Sustained } \\
\text { reduction in } \\
\text { ALT }\end{array}$ & No significant effect \\
\hline 8 & $\begin{array}{l}\text { Malaguarn } \\
\text { era } \quad M \text {, } \\
2010[112]\end{array}$ & 74 patients & $\begin{array}{l}\text { L-Carnitine } \\
\text { supplementat } \\
\text { ion to diet } 1: 1\end{array}$ & 24 weeks & $\begin{array}{l}\text { Liver } \\
\text { biochemistry }\end{array}$ & Significant improvement \\
\hline 9 & $\begin{array}{l}\text { Sanyal A, } \\
2010 \\
\text { (PIVENS) } \\
{[57]}\end{array}$ & 247 patients & $\begin{array}{l}\text { Pioglitazone } \\
\text { vs Vitamin E } \\
\text { vs placebo } \\
1: 1: 1\end{array}$ & 96 weeks & $\begin{array}{l}\text { Improvement } \\
\text { in NAS score }\end{array}$ & $\begin{array}{l}\text { Vitamin E was superior to } \\
\text { placebo, no benefit of } \\
\text { pioglitazone over placebo }\end{array}$ \\
\hline
\end{tabular}




\begin{tabular}{|c|c|c|c|c|c|c|}
\hline 10 & $\begin{array}{l}\text { Leuschner } \\
\text { U, } 2010 \\
{[78]}\end{array}$ & 185 patients & $\begin{array}{l}\text { Ursodeoxych } \\
\text { olic acid } 1: 1\end{array}$ & 18 months & $\begin{array}{l}\text { An overall } \\
\text { improvement } \\
\text { of liver } \\
\text { histology }\end{array}$ & No significant effect \\
\hline 11 & $\begin{array}{l}\text { Vilar } \\
\text { Gomez E, } \\
2009 \text { [113] }\end{array}$ & 60 patients & $\begin{array}{l}\text { Nutritional } \\
\text { supplement } \\
\text { Viusid } 1: 1\end{array}$ & 6 months & $\begin{array}{l}\text { Improvement } \\
\text { in NAS and } \\
\text { fibrosis score }\end{array}$ & $\begin{array}{l}\text { Improvement in the NAS } \\
\text { score but not in fibrosis }\end{array}$ \\
\hline 12 & $\begin{array}{l}\text { Aithal } \\
\text { G.P, } 2008 \\
{[56]}\end{array}$ & 74 patients & $\begin{array}{l}\text { Pioglitazone } \\
1: 1\end{array}$ & 12 months & $\begin{array}{l}\text { Reduction in } \\
\text { hepatocyte } \\
\text { injury and } \\
\text { fibrosis }\end{array}$ & Significant effect \\
\hline 13 & $\begin{array}{l}\text { Ratziu V, } \\
2008 \\
\text { (FLIRT) } \\
\text { [49] }\end{array}$ & 63 patients & Rosiglitazone & 1 year & $\begin{array}{l}\text { Improvement } \\
\text { of steatosis, } \\
\text { necroinflamma } \\
\text { tion \& fibrosis } \\
\text { Normalization } \\
\text { of } \\
\text { transaminases }\end{array}$ & $\begin{array}{l}\text { Improved steatosis } \\
\text { Normalized transaminase } \\
\text { levels } \\
\text { No improvement in fibrosis } \\
\text { and NAS }\end{array}$ \\
\hline 14 & $\begin{array}{l}\text { Lindor K, } \\
2004[77]\end{array}$ & 166 patients & $\begin{array}{l}\text { Ursodeoxych } \\
\text { olic acid } 1: 1\end{array}$ & 2 years & $\begin{array}{l}\text { Histological } \\
\text { and } \\
\text { biochemical } \\
\text { improvement }\end{array}$ & No significant effect \\
\hline
\end{tabular}


Table 2. Ongoing clinical trials with new pharmacologic agents for patients with non-alcoholic steatohepatitis (clinical trials.gov accessed 20 Oct 2016).

\begin{tabular}{|c|c|c|c|c|c|}
\hline $\mathrm{A} / \mathrm{a}$ & $\begin{array}{l}\text { ClinicalTrials.gov } \\
\text { Identifier }\end{array}$ & Phase & Stage & Agent & Action \\
\hline 1 & NCT02704403 & Phase III & Recruiting & $\begin{array}{l}\text { Elafibranor } \\
\text { (GFT505) }\end{array}$ & dual PPAR $\alpha / \delta$ agonist \\
\hline 2 & NCT02654665 & Phase III & Recruiting & $\begin{array}{l}\text { Liraglutide \& } \\
\text { bariatric surgery }\end{array}$ & GLP-1 analogue \\
\hline 3 & NCT02548351 & Phase III & Recruiting & Obeticholic acid & FXR agonist \\
\hline 4 & NCT02541045 & Phase III & Recruiting & Metadoxine & $\begin{array}{l}\text { Pyridoxine-pyrrolidone } \\
\text { carboxylate }\end{array}$ \\
\hline 5 & NCT02605616 & Phase II & Recruiting & A novel AZ agent & \\
\hline 6 & NCT02913105 & Phase II & Not yet recruiting & LMB763 & \\
\hline 7 & NCT02443116 & Phase II & Recruiting & NGM282 & $\begin{array}{l}\text { Recombinant variant of } \\
\text { FGF-19 (FGF-19 is a } \\
\text { peptide hormone) }\end{array}$ \\
\hline 8 & NCT02279524 & Phase IIb & Recruiting & Aramchol & $\begin{array}{l}\text { Conjugate of cholic and } \\
\text { arachidic acid }\end{array}$ \\
\hline 9 & NCT02912260 & Phase II & Recruiting & MGL-3196 & $\begin{array}{l}\text { small-molecule } \\
\text { directed } \beta \text {-selective } \\
\text { agonist }\end{array}$ \\
\hline 10 & NCT02855164 & Phase II & Recruiting & LJN452 & FXR agonist \\
\hline 11 & NCT02854605 & Phase II & Not yet recruiting & GS-9674 & $\begin{array}{l}\text { A synthetic non-steroidal } \\
\text { FXR agonist }\end{array}$ \\
\hline
\end{tabular}




\begin{tabular}{|c|c|c|c|c|c|}
\hline 12 & NCT02927314 & Phase II & Not yet recruiting & CF102 & $\begin{array}{l}\text { A3 adenosine receptor } \\
\text { agonist }\end{array}$ \\
\hline 13 & NCT02856555 & Phase II & Recruiting & GS-0976 & ACC inhibitor \\
\hline 14 & NCT02574325 & Phase II & $\begin{array}{l}\text { Ongoing but not } \\
\text { recruiting }\end{array}$ & $\begin{array}{l}\text { Niacin/ARI- } \\
\text { 3037MO }\end{array}$ & Vitamin B3 analog \\
\hline 15 & NCT02413372 & Phase II & $\begin{array}{l}\text { Ongoing but not } \\
\text { recruiting }\end{array}$ & BMS-986036 & $\begin{array}{l}\text { Pegylated FGF-21 analogue } \\
\text { (FGF-21 is a peptide } \\
\text { hormone) }\end{array}$ \\
\hline 16 & NCT02217475 & Phase II & $\begin{array}{l}\text { Ongoing but not } \\
\text { recruiting }\end{array}$ & Cenicriviroc & $\begin{array}{ll}\text { dual } & \text { CCR2/CCR5 } \\
\text { antagonist } & \end{array}$ \\
\hline 17 & NCT02686762 & Phase II & Recruiting & Emricasan & pan caspase inhibitor \\
\hline 18 & NCT02466516 & Phase II & $\begin{array}{l}\text { Ongoing but not } \\
\text { recruiting }\end{array}$ & $\begin{array}{l}\text { GS-4997 alone or } \\
\text { with simtuzumab }\end{array}$ & inhibitor of ASK1 \\
\hline 19 & NCT02421094 & Phase II & $\begin{array}{l}\text { Ongoing but not } \\
\text { recruiting }\end{array}$ & GR-MD-02 & $\begin{array}{l}\text { A complex carbohydrate } \\
\text { drug that targets galectin-3 }\end{array}$ \\
\hline 20 & NCT02316717 & Phase II & Recruiting & IMM-124E & $\begin{array}{l}\text { is composed of anti-LPS } \\
\text { antibodies and adjuvants, } \\
\text { many of which are } \\
\text { glycosphingolipids, } \\
\text { targeting the } \\
\text { microbiome and the innate } \\
\text { immune system of the gut }\end{array}$ \\
\hline 21 & NCT02784444 & Phase II & Recruiting & MSDC $0602 \mathrm{~K}$ & Insulin sensitizer \\
\hline 22 & NCT02442687 & Phase II & Recruiting & JKB-121 & $\begin{array}{l}\text { Non-selective } \\
\text { antagonist }\end{array}$ \\
\hline
\end{tabular}




\begin{tabular}{|c|c|c|c|c|c|}
\hline 23 & NCT01679197 & Phase II & $\begin{array}{l}\text { Ongoing but not } \\
\text { recruiting }\end{array}$ & Metreleptin & Recombinant human leptin \\
\hline 24 & NCT02681055 & Phase II & Recruiting & MN-001/Tipelukast & $\begin{array}{l}\text { orally bio-available small } \\
\text { molecule compound which } \\
\text { demonstrates anti- } \\
\text { inflammatory activity }\end{array}$ \\
\hline 25 & NCT02510599 & Phase II & Recruiting & $\begin{array}{l}\text { CEM- } \\
\text { 101/Solithromycin }\end{array}$ & $\begin{array}{l}\text { a new generation macrolide } \\
\text { antibiotic }\end{array}$ \\
\hline 26 & NCT01919294 & Phase II & Recruiting & $\begin{array}{l}\text { Testosterone } \\
\text { replacement }\end{array}$ & \\
\hline 27 & NCT01672879 & Phase II & $\begin{array}{l}\text { Ongoing but not } \\
\text { recruiting }\end{array}$ & $\begin{array}{l}\text { GS- } \\
\text { 6624/Simtuzumab }\end{array}$ & $\begin{array}{l}\text { Humanized anti-LOXL2 } \\
\text { monoclonal IgG4 antibody }\end{array}$ \\
\hline 28 & NCT01672866 & Phase II & $\begin{array}{l}\text { Ongoing but not } \\
\text { recruiting }\end{array}$ & $\begin{array}{l}\text { GS- } \\
6624 / \text { Simtuzumab }\end{array}$ & \\
\hline 29 & NCT02923154 & Phase II & Recruiting & MT-3995 & $\begin{array}{l}\text { a selective aldosterone } \\
\text { receptor antagonist }\end{array}$ \\
\hline 30 & NCT02612662 & Phase I & Recruiting & $\begin{array}{l}\text { AZD4076/RG-125 } \\
\text { (tetracosasodium) }\end{array}$ & $\begin{array}{l}\text { an anti-Mir directed against } \\
\text { miR-103/107 }\end{array}$ \\
\hline 31 & NCT02469272 & Phase I & Recruiting & $\begin{array}{l}\text { Fecal microbiota } \\
\text { transplantation }\end{array}$ & 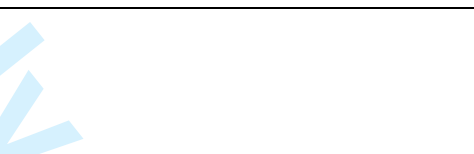 \\
\hline 32 & NCT02721264 & & Recruiting & $\begin{array}{l}\text { Fecal microbiota } \\
\text { therapy }\end{array}$ & \\
\hline 33 & NCT02196831 & & Recruiting & Tesamorelin & GHRH analogue \\
\hline
\end{tabular}

PPAR, peroxisome proliferator-activated receptor; GLP, glucagon-like peptide; FXR, farnesoid X receptor; FGF, Fibroblast Growth Factor; THR, thyroid hormone receptor; ACC, Acetyl-CoA carboxylase; CCR, CC- 
chemokine receptor; ASK, apoptosis signal-regulating kinase; LPS, lipopolysaccharide; LOXL, lysyl oxidaselike protein; GHRH, growth hormone-releasing hormone 